Original Research

\title{
Research on Holocene Loess Erosion Associated to Climate Evolution in China
}

\author{
Chen Yao $^{1,2 *}$, Huo Wuxing ${ }^{3}$, Qian Hui ${ }^{1,2}$, Li Bingcheng ${ }^{1,2}$ \\ ${ }^{1}$ School of Environmental Science and Engineering, Chang'an University, Xi'an, China \\ ${ }^{2}$ Key Laboratory of Subsurface Hydrology and Ecological Effect in Arid Region of the Ministry of Education, \\ Chang'an University, Xi'an, China \\ ${ }^{3}$ School of Highways, Chang'an University, Xi'an, China
}

Received: 8 October 2018

Accepted: 22 November 2018

\begin{abstract}
Loess is the carrier for the Chinese nation's survival, and we can accurately know its erosion changes since the Holocene, the current period of geologic time, which is very important to predict future trends. However, there is very limited quantitative research on Holocene climate change and loess erosion intensity. This research takes the Holocene loess depositional sequence of Shaolingyuan in Xi'an at southern loess plateau as the research object to analyze the magnetic susceptibility and stratigraphic age structure of sedimentary sequences, and describe the climate change in different periods. This method uses the sensitivity of pedogenes and fits the precipitation and temperature equation to quantitatively reconstruct the paleoprecipitation and paleotemperature changes since the Holocene, which determines the relationship between soil erosion intensity and precipitation in order to estimate soil erosion intensity since the Holocene period. Results show that the climate change in Xi'an is as follows: $10000 \sim 8400$ a B.P. is the cold temperature transition stage; $8400 \sim 7000$ a B.P. is the warm-cold fluctuation stage; 7000 5000 a B.P. is the warm temperature stage; $5000 \sim 3400$ a B.P. is the warm-cold violent fluctuation stage; and $3400 a$ B.P. is the warm-semi-humid and semi-arid stage. The Holocene soil erosion intensity changes with annual average precipitation. At 9700 a B.P., the annual average rainfall is $676.6 \mathrm{~mm}$, the Estimate of soil erosion intensity reaches its peak value $\left(1287.7 \mathrm{Mg} \cdot \mathrm{km}^{-2} \cdot \mathrm{a}^{-1}\right)$, and the soil erosion intensity will become more serious for some time in the future. This research proposes a new method for estimating soil erosion intensity changes caused by climate change, which not only infers the relationship between soil erosion intensity and climate change, but also provides a theoretical basis for accurately processing the soil and water conservation works in the loess area.
\end{abstract}

Keywords: climate evolution, loess erosion, Shaolingyuan, Holocene 


\section{Introduction}

The Holocene, as the most recent interglacial period and as a time with an abundance of highly resolved paleoclimate archives, presents an opportunity to understand the dynamics of the Earth system [1]. The existence of loess has promoted the development of Chinese farming, thus promoting the rise and prosperity of ancient Chinese civilization [2-4]. Climate change since the Holocene has led to the erosion of surface layer loess in different degrees [5-6], which not only affects the development of agriculture and industry in the loess area, but also causes a series of environmental geological problems [7-9] such as river bed uplift and chemical pollution, etc. Soil erosion in the loess area is generally the result of the interaction of natural conditions and human activities, such as heavy rainfall, vegetation coverage, and human over-cultivation and grazing behavior [10-13]. China's Loess Plateau is located in the middle and lower reaches of the Yellow River. Most of the plateau belongs to the semi-arid continental monsoon climate, which is one of the areas most affected by soil erosion and water and soil losses in the world [7]. Besides, with the intensification of human activities since the Holocene, the loess layer in this area has been particularly seriously eroded and destroyed. Therefore, the soil and water conservation practices on the Loess Plateau should reduce total soil erosion intensity (including the soil erosion intensity caused by human activities and natural erosion) to near or even lower than the soil erosion intensity caused by nature. However, the soil erosion intensity caused by natural conditions is not constant in different geological periods [14]. Some scholars have shown that the natural erosion intensity of the Holocene is mainly dominated by climate change. To estimate the natural erosion intensity of Holocene soil, the primary objective is to understand the feedback mechanism of climate change information [15-16].

There are many intact Holocene stratum in Xi'an at the southern Guanzhong Basin, which contains abundant information about the evolution of paleoclimate in this site, and it is also a good carrier for paleoclimate change research [17-18]. Many scholars have done several studies on the evolution of Holocene loess to paleoclimate and the environment in Xi'an, providing a scientific basis for predicting the climate change trend in this area. In addition, other researchers have developed quantitative methods to estimate soil erosion intensity since Quaternary on the whole Loess Plateau [19]. The commonly used methods include estimating soil erosion intensity based on ravine volume and estimation in accordance with the sediments from the Yellow River Delta, Bohai continental shelf and river terrace [20-21]. Nevertheless, these methods are practical and it's difficult to provide links between climate change and soil erosion. Studies have shown that there is indeed a functional relationship between both [22-24]. Although this functional relationship is not unique, the relationship between sediment yield and precipitation in different regions follows a similar rule, which is known as the Langbein-Schumm curve [25]. These types of curves are mainly related to climatic conditions and land use patterns. Without considering the human activities, land use patterns are mainly controlled by natural vegetation, which is expressed as net primary productivity index $\left(N P P, \mathrm{Mg} \cdot \mathrm{ha}^{-2} \cdot \mathrm{a}^{-1}\right)$ [26]. It is worth noting that the sediment delivery ratio of the Loess Plateau is close to 1. Therefore, if the annual average precipitation and $N P P$ in the Loess Plateau are known, the soil erosion intensity in different geological periods can be estimated according to the Langbein-Schumm curve.

Based on the mentioned analysis, this paper selects a well-preserved Holocene loess sedimentary sequence in southern Xi'an as the research object to: (1) Research the climate change since Holocene in Xi'an; (2) Reconstruct the paleotemperature and paleoprecipitation since Holocene; and (3) Estimate the relationship between soil erosion intensity and Holocene climate change.

\section{Material and Methods}

\section{Study Area and Data}

The research area is located in the southern Loess Plateau, south of the Weihe River, and on the

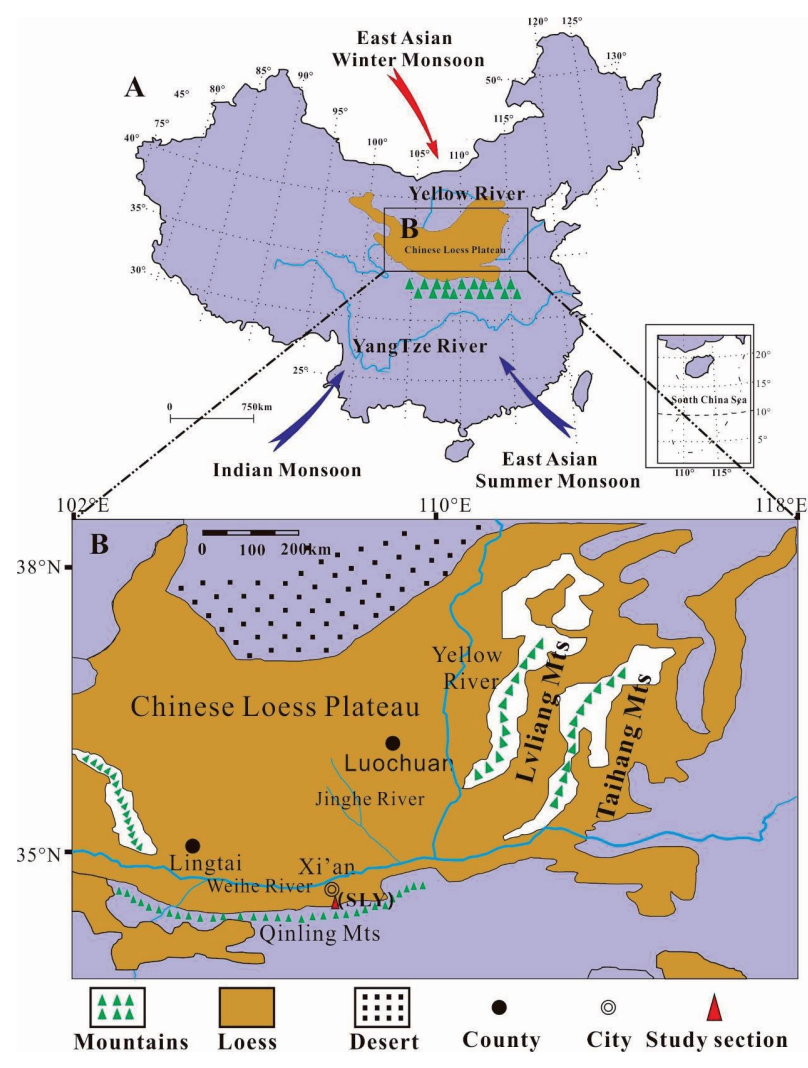

Fig. 1. Location of the Xi'an study sites in the southern Loess Plateau of China. 
Shaolingyuan (SLY Chang'an District of southern Xi'an suburb; Fig. 1). The plateau can be divided into different parts according to grain size from northwest to southeast: sandy loessial zone, silt loess zone and viscoloess zone. The sequence of SLY loess deposition should belong to the visco-plastic loess zone [27]. At present, the vegetation is mainly drought-tolerant herbs and temperate deciduous broad-leaved forests. The average annual temperature is about $13.7^{\circ} \mathrm{C}$ and average annual rainfall reaches $719.5 \mathrm{~mm}$. Affected by the alternation of winter and summer monsoon, it is cold and rainless in winter, but warm and rainy in summer, which is the typical temperate monsoon climate. The tableland of the study area is tilted from southeast to northwest, with slight fluctuation.

In the sampling process, in order to reduce the effects of weathering, plant and animal residues and human activities on the test results, the surface soil was removed for 1-2 $\mathrm{m}$ first, and then 180 samples were collected at an interval of $1 \mathrm{~cm}$ down from the surface according to the age-depth relationship of the loess depositional sequence in this area. Each sample was collected as $500 \mathrm{~g}$ loose soil in a sealed bag with sampling depth of about $1.80 \mathrm{~m}$. The lithology and structure of the SLY profile are shown in Table 1.

\section{Experiment Design}

${ }^{14} \mathrm{C}$ dating: We collected the scattered earth samples back to the lab, and selected three samples as the control points after air drying at room temperature, then picked out the gravels and visible roots and passed them through a $2 \mathrm{~mm}$ sieve. Finally, we carried out the $A M S^{14} C$ dating in the Xi'an Accelerated Mass Spectrometry Center of the Institute of Earth Environment, Chinese Academy of Sciences. Take out the $\mathrm{CO}_{2}$ from the pretreated sample through system combustion, and use $\mathrm{Li}$ [28] and other descriptive methods to return the purified $\mathrm{CO}_{2}$ to $A M S$ graphite target, so that it can get the age of $S L Y$ profile control points.

Magnetic susceptibility measurement: Samples were air dried at room temperature, then ground to $20 \mathrm{~g}$ powder and placed in small plastic bags. After accurately measuring the sample quality, we used a Magnetic-susceptibility Model-942 susceptibility meter to measure as to reduce the measurement error, and the average value of each sample was taken three times. We divided its quality to obtain the magnetic susceptibility value of strata.

\section{Data Analysis}

Determining chronological sequence. Thickness and susceptibility product of loess sedimentary sequence are proportional to the deposition time. From previous research [29], the absolute age of each stratum can be accurately measured by combining the ${ }^{14} \mathrm{C}$ dating data of control points on the $S L Y$ profile, and the formula of magnetic susceptibility age is as follows:

$$
T_{m}=T_{0}+\left(T_{1}-T_{0}\right)\left(\sum_{i=1}^{m} a_{i} \chi_{i}\right)\left(\sum_{i=1}^{n} a_{i} \chi_{i}\right)^{-1}
$$

...where $T_{m}$ is the absolute age of required stratum; $T_{0}$, $T_{1}$ are the ages of control points; $\mathrm{n}$ is the total position of the two control points; $m$ is the total down position of required stratum; a is the thickness of single stratum; and $\chi$ is the magnetic susceptibility value $\left(10^{-7} \mathrm{~m}^{3} \cdot \mathrm{kg}^{-1}\right)$ of corresponding stratum. The final calculation result is shown in Fig. 2.

Palaeoclimate reconstruction. Loess magnetic susceptibility is an adequate index for studying the Quaternary climate change the Loess Plateau, providing a quantitative basis for paleo-rainfall and paleotemperature changes. A large number of studies have shown that magnetic susceptibility has a functional relationship with precipitation and temperature, and the related equations have been established [30]. The following equations are based on abundant sampling data from the Loess Plateau:

$$
\begin{gathered}
M A P=-22.706+11.554 \chi-6.7166 \times 10^{-2} \chi^{2}+ \\
1.8684 \times 10^{-4} \chi^{3}-1.9264 \times 10^{-7} \chi^{4} \\
\left(n=63, R^{2}=0.675\right)
\end{gathered}
$$

Table 1. Stratigraphic features and soil horizon designations of soil profiles on the study site.

\begin{tabular}{|c|c|c|c|}
\hline $\begin{array}{c}\text { Soil } \\
\text { horizons }\end{array}$ & Depth $(\mathrm{m})$ & $\begin{array}{c}\text { Stratigraphic } \\
\text { subdivisions }\end{array}$ & Pedological description \\
\hline A1 & $0 \sim 0.15$ & Top soil $(T S)$ & $\begin{array}{r}\text { Gray yellow, fine particles, uniform texture, loose structure, gap development, rich in } \\
\text { plant roots,tile contained that should be disturbed soil. }\end{array}$ \\
\hline A2 & $0.15 \sim 0.50$ & $\begin{array}{c}\text { Holocene loess } \\
(L O)\end{array}$ & $\begin{array}{r}\text { Grayyellow, fine particles, strong viscosity, large gap development, containing plant } \\
\text { roots and a small number of calcareous nodules. }\end{array}$ \\
\hline B & $0.50 \sim 1.45$ & Paleosoil $(S 0)$ & $\begin{array}{c}\text { Brownish red, the granules are finer and more viscous than upper layer,the clay } \\
\text { surface is smooth and in prismatic structure, root wormhole and white calcium mem- } \\
\text { brane develop. }\end{array}$ \\
\hline $\mathrm{C}$ & $1.45 \sim 1.80$ & $\begin{array}{c}\text { Malan Loess } \\
(L 1)\end{array}$ & $\begin{array}{c}\text { Exposure 0.35 m (not see the bottom), color develops from gray yellow to light gray } \\
\text { brown, uniform texture, no bedding, loose structure, large gap development, calcium } \\
\text { contained, thick deposition layer; }\end{array}$ \\
\hline
\end{tabular}




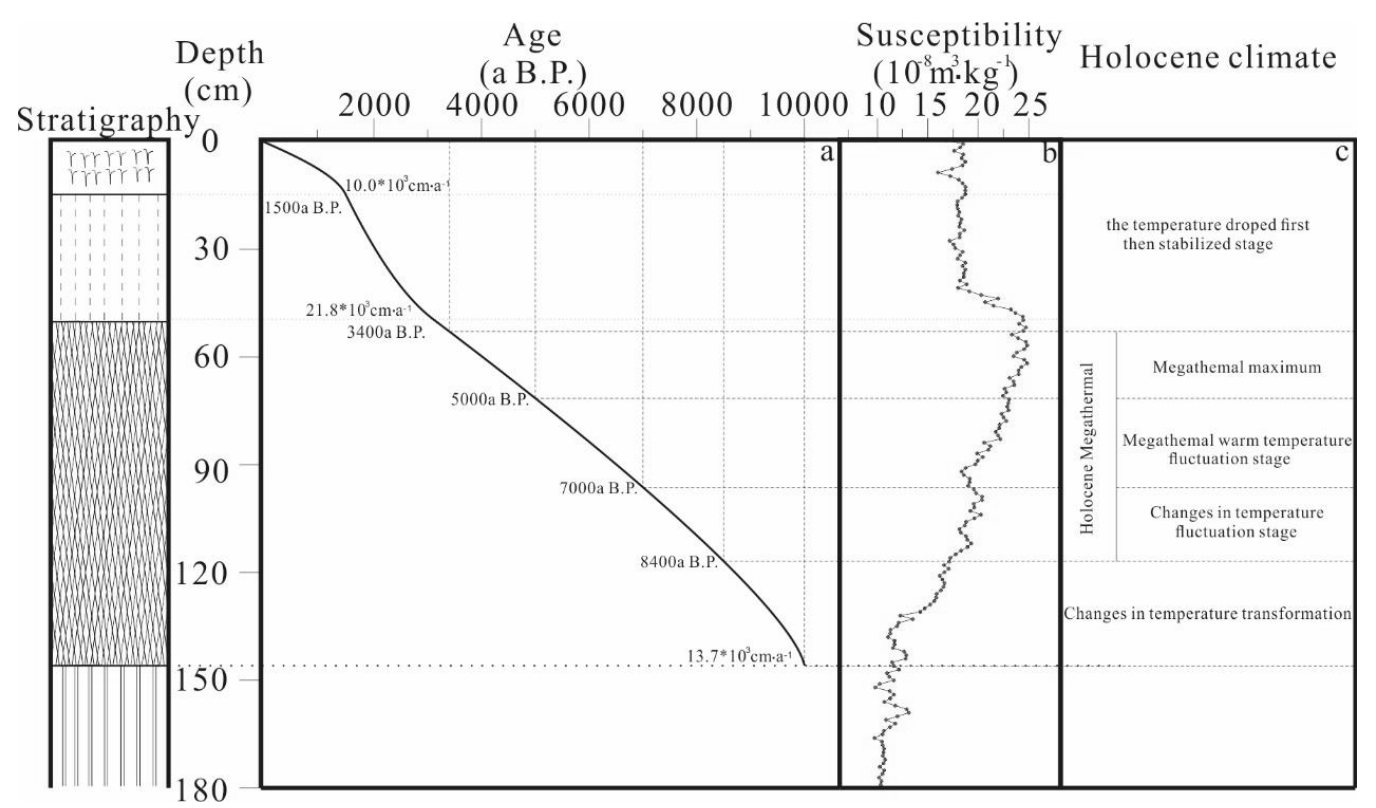

Fig. 2. Magnetic susceptibility age-depth model for SLY profile and Holocene climate change.

$$
\begin{gathered}
M A T=-2.3731+0.21567 \chi-1.1053 \times 10^{-3} \chi^{2}+ \\
2.7069 \times 10^{-6} \chi^{3}-2.6525 \times 10^{-9} \chi^{4} \\
\left(\mathrm{n}=63, \mathrm{R}^{2}=0.718\right)
\end{gathered}
$$

...where $M A P$ is average annual rainfall (mm); MAT is mean annual temperature $\left({ }^{\circ} \mathrm{C}\right)$; and the dimension of $\chi$ is $10^{-8} \mathrm{~m}^{3} \cdot \mathrm{kg}^{-1}$.

Correlation equation between rainfall erosion and precipitation. According to a large amount of research data, the relationship between rainfall erosivity (Re, $\left.\mathrm{MJ} \cdot \mathrm{cm} \cdot \mathrm{ha}^{-1} \cdot \mathrm{a}^{-1}\right), N P P$ and MAP of the Loess Plateau can be described following two equations:

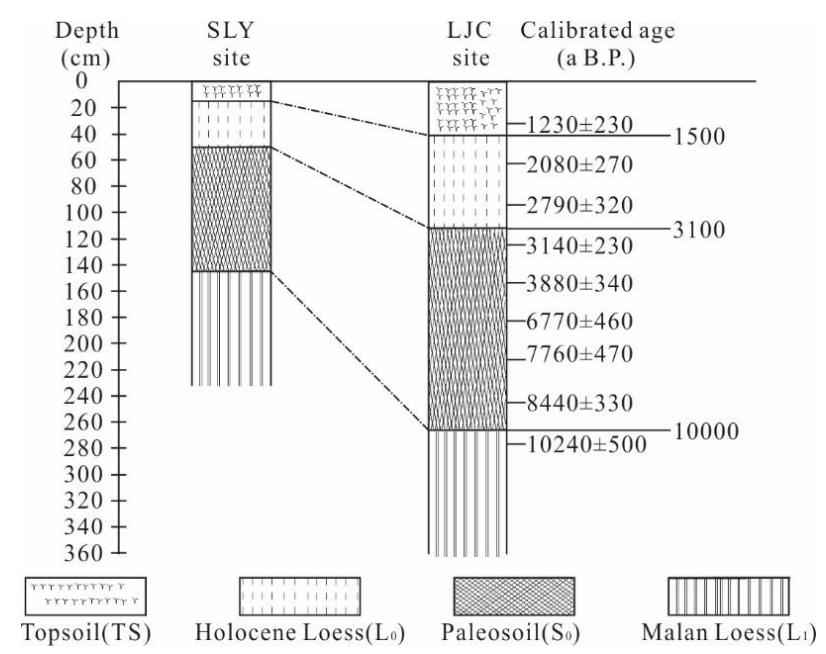

Fig. 3. Pedo-stratigraphic correlations of the studied loesspaleosol sequences (LJC, LiuJiacun profile).

$$
\begin{array}{ll}
R_{e}=18.308 e^{0.0036 M A P} & \left(\mathrm{n}=152, \mathrm{R}^{2}=0.591\right) \\
1 / N P P=10^{9} M A P^{-3.6341} & \left(\mathrm{n}=283, \mathrm{R}^{2}=0.801\right)
\end{array}
$$

As discussed previously, the soil erosion intensity is mainly determined by $M A P$ and $N P P$, and there is a nonlinear relationship between $R e$ and precipitation. Here, soil erosion intensity $\left(I_{e}, \mathrm{Mg} \cdot \mathrm{km}^{-2} \cdot \mathrm{a}^{-1}\right)$ is defined as annual erosion per square kilometer. According to the data of 64 county-level administrative regions published by the Loess Plateau before 1980, it was found that $I_{e}$ is related to MAP. Since the state's soil and water conservation policy on the Loess Plateau has not been fully implemented [31], it can be considered that the natural erosion intensity of the soil should be dominant at this time.

\section{Results and Discussion \\ Determining Stratigraphic Age and Sedimentation Rate}

Fig, 3 shows that the deposition rate of loess and paleosoil on the $S L Y$ profile is related to the sedimentary geological environment. Since the Holocene, the sedimentation rate of loess is higher than that of paleosoil, and the average sedimentation rate can reach $21.8 * 10^{3} \mathrm{~cm} \cdot \mathrm{a}^{-1}$. However, the sedimentation rate of paleosoil is only $13.7 * 10^{3} \mathrm{~cm}^{-a^{-1}}$. Here we found a substantial difference between their sedimentation rates [32].

According to the gained results and the data of previous researchers, the age of each layer boundary point of the SLY Holocene is determined: the test age 
of the late Pleistocene Ma Lan loess and Holocene paleosoil boundary is $9800 \pm 35$, which is temporarily set as 10000a; for the boundary between the Holocene palaeosoil and the Holocene Loess bottom, the test data is $3120 \pm 35 \mathrm{a}$, which is temporarily set as $3400 \mathrm{a}$; for the boundary age of late Holocene and plough horizon, the test data is $1580 \pm 25 \mathrm{a}$, which is temporarily set as1500 a. The rest of the area is derived from previous data.

\section{Holocene Climate Change}

Fig. 2 shows the magnetic susceptibility curve of the SLY profile since the Holocene. Magnetic susceptibility has been proven to be a reliable paleoclimate alternative indicator, indicating the concentration of moderately and ultrafine ferromagnetic particles in loess pedogenesis [33-34]. As the pedogenesis is affected by deposition climate, $\chi$ records the pedogenesis variable intensity caused by climate. It is not difficult to find that the lowest value of SLY profile $\chi\left(10.53 \times 10^{-7} \mathrm{~m}^{3} \cdot \mathrm{kg}^{-1}\right)$ appeared in Malan loess before $10000 a$, which gradually increased from 10000 to 3400 a B.P. Its peak value $\left(25.06 \times 10^{-7} \mathrm{~m}^{3} \mathrm{~kg}^{-1}\right)$ appears in the upper paleosoil. Therefore, $\chi$ has declined in Holocene loess and plough layer. The trend of $\chi$ change shows that 10000 a B.P. loess pedogenesis and precipitation and temperature in the same period are at relatively low level, which also reflects the characteristics of the dominant winter climate change from cold and dry to warm, hot and damp in the Holocene. The characteristics of magnetic susceptibility of paleosoil from 10000 3400 a B.P. reflect the characteristics of strong summer monsoon dominant soil pedogenesis, high magnetic susceptibility and warm climate in Holocene.

\section{Paleoprecipitation and Paleotemperature Reconstruction}

Equations (2) and (3) are used to estimate the annual rainfall and temperature changes in Xi'an since the Holocene. Fig. 4 shows that the lowest rainfall $(643 \mathrm{~mm})$ and the lowest temperature $\left(10.91^{\circ} \mathrm{C}\right)$ all occur in $10000 a$ B.P., and then gradually increase to 3400 a B.P. and reach peak values $\left(841 \mathrm{~mm}, 14.42^{\circ} \mathrm{C}\right)$. However, with the invasion of the ice age, the two have gradually declined. The estimated value of SLY profile: rainfall is $764.57 \mathrm{~mm}$, and the temperature is $13.57^{\circ} \mathrm{C}$, which is very close to the annual average precipitation $(715 \mathrm{~mm})$ and annual average temperature $\left(13.3^{\circ} \mathrm{C}\right)$ in $\mathrm{Xi}$ 'an at present, which confirms the rationality of this method.

\section{Soil Natural Erosion Intensity}

Some scholars obtained the equation between Ie and $M A P$ by fitting the annual average precipitation and soil erosion data of county-level administrative regions in the Loess Plateau in the 1980s [31].

$$
\begin{aligned}
I_{e}= & 1 /\left(3.594 \times 10^{-3}-1.524 \times 10^{-5} M A P+\right. \\
& \left.1.637 \times 10^{-8} M A P^{2}\right) \quad\left(\mathrm{n}=64, \mathrm{R}^{2}=0.639\right)
\end{aligned}
$$

From the above equations we can see that $63 \%$ of the change of soil erosion intensity is caused by precipitation, and the results of the equation's $F$ test show statistical significance under $99 \%$ confidence level.

In the early depositional stage of the Loess Plateau, the terrain is relatively flat and continuous,

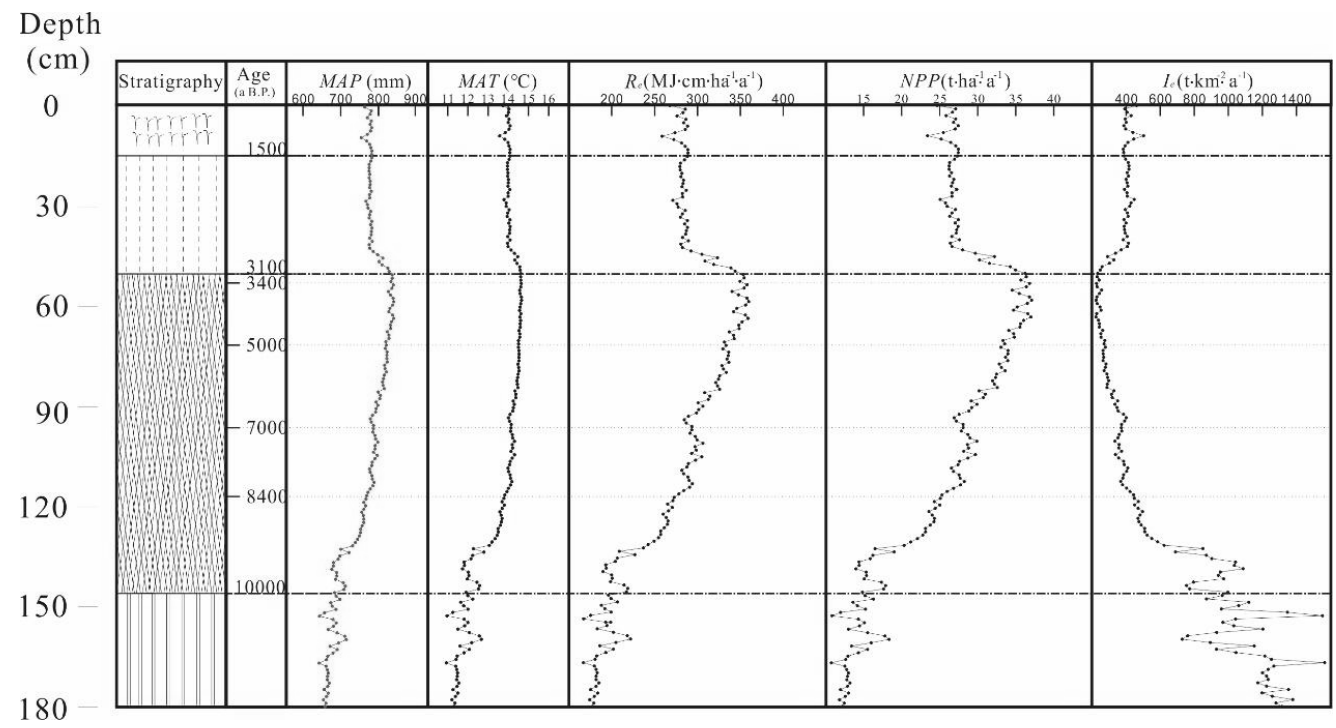

Fig. 4. Variation of calculated (1) mean annual paleoprecipitation $(M A P),(2)$ mean annual paleotemperature (MAT), (3) rainfall erosivity $(R e),(4)$ net primary productivity $(N P P)$, and (5) soil erosion intensity (Ie) during the Holocene in SLY profiles. 


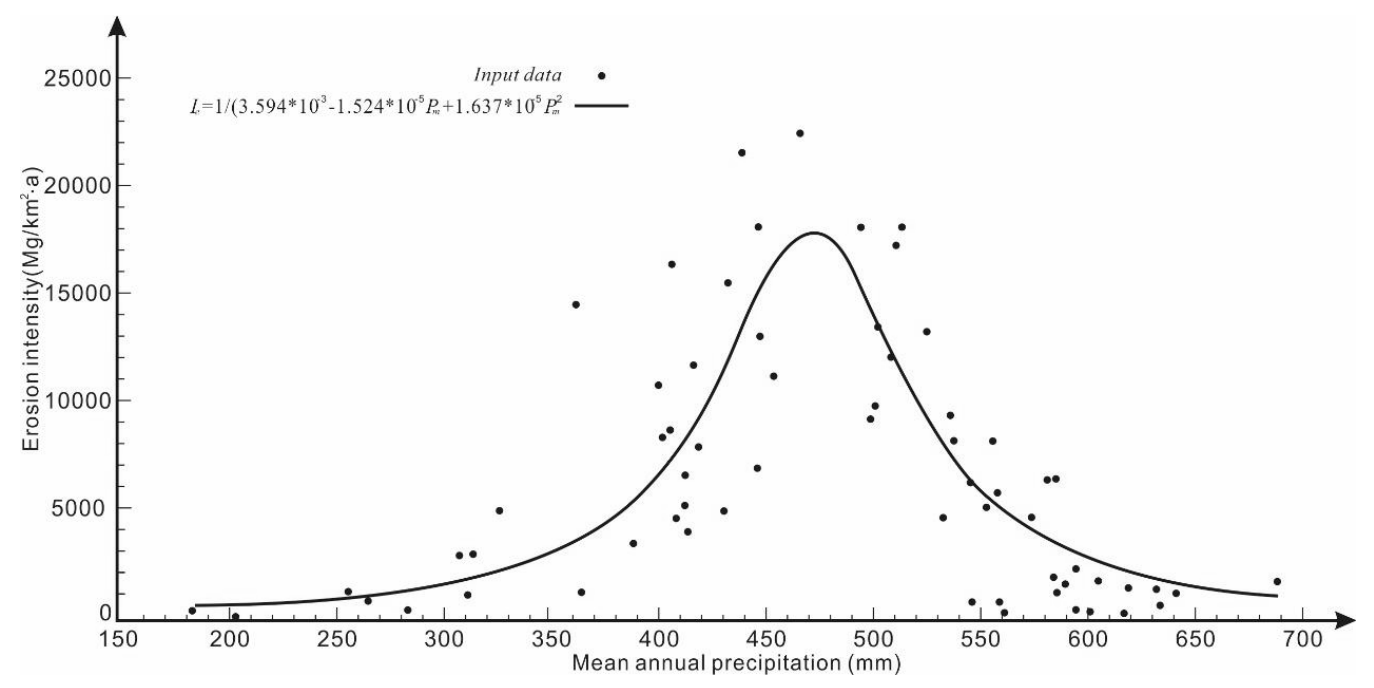

Fig. 5. Soil erosion intensity (Ie) as a function of mean annual precipitation $(\mathrm{Pm})$.

and the whole area is almost completely covered by thick loess. As discussed earlier, the grain size of loess deposits under the influence of monsoon gradually coarsen from southeast to northwest, which makes it possible to evaluate the intensity of soil erosion in the past by spatial sequence method. Based on the above description, the mathematical model is established to estimate $I e$.

Results of Re, NPP and $I e$ in the Holocene loess strata in Xi'an calculated by equations (4), (5) and (6) are shown in Fig. 6. When precipitation increases from 680 to $720 \mathrm{~mm}$, Re also increases from 220 to $233 \mathrm{MJ} \cdot \mathrm{cm} \cdot \mathrm{ha}^{-1} \cdot \mathrm{a}^{-1}$, but NPP value is at a lower level $\left(22 \mathrm{Mg} \cdot \mathrm{ha}^{-2} \cdot \mathrm{a}^{-1}\right)$. At about 5000 a B.P. precipitation rises to $821 \mathrm{~mm}, \mathrm{Re}$ increases by $50 \%$ to $351 \mathrm{MJ} \cdot \mathrm{cm} \cdot \mathrm{ha}^{-1} \cdot \mathrm{a}^{-1,}$, and NPP also rapidly grows from $77.2 \%$ to $39 \mathrm{Mg} \cdot \mathrm{ha}^{-2} \cdot \mathrm{a}^{-1}$. Surprisingly, $I_{e}$ declines from 11989 to $472 \mathrm{Mg} \cdot \mathrm{km}^{-2} \cdot \mathrm{a}^{-1}$, and the minimum appears in the paleosoil. Soil erosion intensity remains relatively low in the paleosoil layer, and decreases with the increase of precipitation. In the past $3400 \mathrm{a}$, due to the colder and drier climate, the sedimentary strata are affected and the soil erosion intensity increased, which is $I_{e}$ increased from 4329 to $6289 \mathrm{Mg} \cdot \mathrm{km}^{-2} \cdot \mathrm{a}^{-1}$.

\section{Paleoclimate Evolution}

Fig. 5 shows the rising trend of $M A P$ and $M A T$ in Xi'an since the Holocene. In fact, the restoration of dry-cold climate is found throughout the Loess Plateau during the late Pleistocene and early Holocene [35-36]. The warm and humid climate of the Holocene ranges from 8500 to 3400 a B.P. (Fig. 2). According to the data observed by paleontological, sporopollen, palaeontological and archaeological indicators [37], China's East Asian continent is indeed in the Holocene warm period between 8500 and $3000 a$ B.P. These records are generally consistent with this research.
The magnetic susceptibility curves of SLY profile are compared with the sporopollen data curves of the Loess Plateau, eastern Hebei Province and the western Changbai Mountains [38-39]. The results show that the susceptibility curves of $S L Y$ profile have good contrast and similar morphology. This also provides more powerful evidence for more accurate analysis of the paleoclimate environment changes in Xi'an since the Holocene. Based on the variation rule of magnetic susceptibility curve in Xi'an, the Holocene climate is divided into:

1. The temperature of $10000 \sim 8400$ a B.P. enters the relative humid and hot period from dry and cold. According to the sporopollen analysis, the pollen of

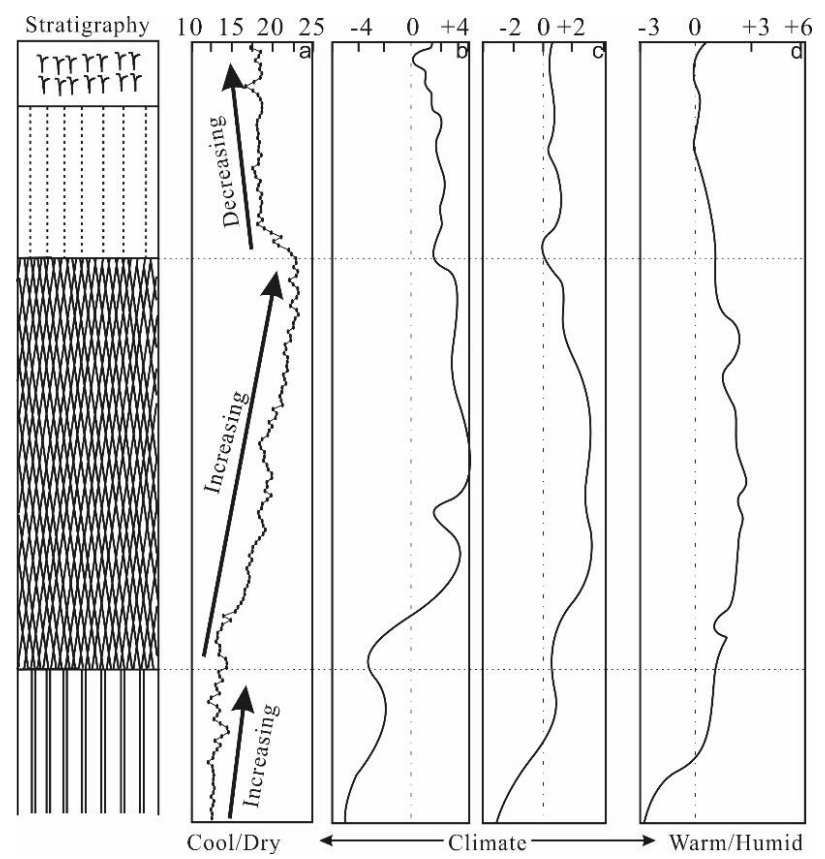

Fig. 6. Contrast of susceptibility cure and sporollen spectrum temperature cure in SLY profiles. 
Mesozoic herbaceous plants in Xi'an was dominant at this stage, reaching $99.5 \%$. At that time, the vegetation type was meadow grassland, which should be a semi-arid climate in the middle temperate zone. Compared with the glacial climate represented by the Malan Loess, the climate had turned warm and the rainfall increased.

2. 8400 3400 a B.P. Holocene Megathermal. The period lasted for $5000 \mathrm{a}$, which had many climate changes and cold events. Therefore, this stage took 7000 and 5000 a B.P. as nodes, and it was divided into 3 climatic stages. (i) 8400 7000 a B.P., in the early stage of the curve, the temperature is higher and the climate is warm and humid, but in the later stage, the temperature fluctuation is more serious. There are two sudden drops in 7800 and $7300 a$ B.P., which coincide with two temperature drops in the "Dunde ice core" [38] around 7800 and 7300 a $B . P$. It can be considered as a cooling event under the background of the Holocene Megathermal period (ii) 7000 5000 a B.P. and the overall performance rose slightly. The data of sporopollen spectrum shows that there were coniferous broad-leaved mixed forests or forest grasslands containing hemlock in Xi'an at that time. The extensive growth of hemlock proved that it had reached the stage of high temperature and relative humidity. (iii) 5000 3400 a B.P., although the magnetic susceptibility value was high at this time, overall more obvious fluctuations have appeared until the periodic trough appeared about 4000 a B.P., which should be a cooling period. At this time, the Holocene Megathermal period basically ended.

3. 3400 a B.P. until now, after a small decrease, the magnetic susceptibility curve tends to be stable and the overall is at a higher level, indicating that the climate is unstable at this time, and the overall is not too bad. The climate is higher and the rainfall is more abundant compared with the Ma Lan loess deposit before the Holocene, according to previous sporopollen spectrum data, and the vegetation type should be sparse forest grassland and the climate type should be warm and semi-humid and semi-arid.

The above results are similar to the results at the central region of the Loess Plateau, but there are slight differences in time nodes. For example, during the Holocene Megathermal Period, the central part of the Loess Plateau was identified as between 8500 3000 a B.P., which was100a earlier started and 400a later ended of the 8400 3400 a B.P. obtained in this paper. Therefore, in order to describe the Holocene climate change characteristics of the Loess Plateau, we should pay attention to the influence of temporal and spatial changes.

\section{Holocene Soil Erosion}

Fig. 5 shows that soil erosion intensity peaked around 9700 a B.P. in the early Holocene $\left(1287 \mathrm{Mg} \cdot \mathrm{km}^{-2} \cdot \mathrm{a}^{-1}\right)$. This value does not appear in
Table 2. Datum of age measuring of AMS14C of loess section during the Holocene in SLY of Xi'an.

\begin{tabular}{|c|c|c|c|}
\hline Sample & Depth/m & Soil type & $\begin{array}{c}\mathrm{AMS}^{14} \mathrm{C} / a \\
\text { B.P. }\end{array}$ \\
\hline SL001 & 0.15 & Holocene loess & $1580 \pm 25$ \\
\hline SL002 & 0.5 & Paleosol & $3120 \pm 35$ \\
\hline SL003 & 1.45 & Malan loess & $9800 \pm 35$ \\
\hline
\end{tabular}

the warmest, humid climate, nor in the coldest, dry conditions. Deng and Yuan [40] believe that the severe stage of soil erosion intensity on the Loess Plateau should occur in the wet and warm stage when the precipitation is large. However, Du and Zhao [41] insist that both cold and dry climates cause soil erosion. Although the precipitation is small, low vegetation coverage can cause large-scale soil erosion. Some scholars believe that soil erosion is more intense during the transition from dry-cold to warm-wet than during the extreme climate of humid-hot or dry-cold, which is consistent with our research results.

In fact, the peak of soil erosion intensity, as expected, is caused by high-frequency rainstorms, loose loess and low vegetation coverage. At present, the analysis of these three main factors is mostly in the qualitative stage, such as describing climate conditions (such as damp, moist, warm, cool, cold and dry) and soil erosion (such as severe and fragile). The relationship between these factors is speculative. According to the LangbeinSchumm curve, the Loess Plateau was in the arid region during the glacial period, and the surface was almost bare. The sparse desert shrubs have very weak protective effect on the surface material. However, because of the little rainfall, the erosion intensity of water flow is very low, and wind erosion is the main factor in such areas [42]. In the watershed from arid to semi-arid areas, the increase of effective rainfall first leads to the rapid increase of erosivity (mainly concentrated rainstorm), while the vegetation in the watershed is not flourishing herbaceous plants, and the increase of anti-erosivity is not enough to counterbalance with erosivity [22]. Therefore, with the increase of rainfall in a semi-arid area, the erosion intensity will also increase rapidly.

Therefore, it is difficult to accurately estimate the influence of rainfall, vegetation coverage type and loose loess on soil erosion. Although the proposed method for calculating soil erosion intensity caused by Holocene climate change cannot fully reflect human activities, the trend of soil erosion caused by climate change has been reflected. From results, we can know that soil erosion will become for some time in the future. The intensity of human-induced soil erosion may be overestimated in this study, but it is still a good method for the change of long-term natural erosion.

It is worth noting that the Holocene climate anomalies may also lead to changes in soil erosion intensity on the Loess Plateau. The limitation of 
the method proposed in this paper is that it is difficult to find a complete Holocene sedimentary profile without considering the interference, especially in Xi'an.

\section{Conclusions}

(1) The SLY profile of Xi'an in the southern Loess Plateau was investigated. Results show that the Holocene climate change in this area can be divided into the following stages: 10000 8400 a B.P. is the coldtemperature transition stage; $8400 \sim 7000 a$ B.P. is the warm-cold fluctuation stage; 7000 5000 $a$ B.P. is the warm-cold fluctuation stage; 5000 3400 $a$ B.P. is the warm-cold violent fluctuation stage; and 3400 a B.P. until now is the warm-semi-humid and semi-arid stage. Accordingly, the climate fluctuation in Xi'an is consistent, periodic, unstable and tendentious with the climate change in Northwest China and even in the whole world.

(2) According to climatic information reflected by the Holocene magnetic susceptibility characteristic curve, we estimated the paleoprecipitation and paleotemperature. It was found that the Holocene paleoprecipitation in Xi'an is consistent with the paleotemperature change trend, and maintains a higher level during the Holocene warm period (8400 3400 a B.P.), which is relatively stable from 3400 a B.P. to now. On this basis, soil erosion intensity, net primary productivity and rainfall erosivity are estimated to explain the change of soil erosion intensity. Our mathematical model shows that the soil erosion intensity in Xi'an increases gradually from $975.6 \mathrm{Mg} \cdot \mathrm{km}^{-2} \cdot \mathrm{a}^{-1}$ at 10000 a B.P. to 1287.1 $\mathrm{Mg} \cdot \mathrm{km}^{-2} \cdot \mathrm{a}^{-1}$ at 9700 a B.P. Then it drops to $1198.9 \mathrm{Mg} \cdot \mathrm{km}^{-2} \cdot \mathrm{a}^{-1}$ before 5000 a B.P., and decreases to $4329.1 \mathrm{Mg} \cdot \mathrm{km}^{-2} \cdot \mathrm{a}^{-1}$ around 3400 a B.P., which finally fluctuates and rises to $6289 \mathrm{Mg} \cdot \mathrm{km}^{-2} \cdot \mathrm{a}^{-1}$. From the resulting information we can see that the soil erosion will become more serious in the future.

This research provides a new method for quantitative estimation for the change of soil erosion intensity caused by climate change in Xi'an since the Holocene. This method not only can estimate soil erosion intensity changes with variation of climate, but also provides a basis for controlling soil and water conservation work.

\section{Acknowledgements}

We would like to extend our deepest gratitude to the reviewers for helpful comments that improved this manuscript considerably. The research was supported by the Special Fund for Study on Micro-scale Hydrological Ecology (310829173306), the Study on Drought Warning and Water Resources Allocation in Arid Areas and Semi-arid Regions (310829173701), and the Study on
Water Resources Management in the Hydrological Cycle (310829172202).

\section{Conflict of Interest}

The authors declare no conflict of interest.

\section{References}

1. FRITZ S.C. The climate of the Holocene and its landscape and biotic impacts. Te.llus Series B-chemical \& Physical Meteorology, 65 (65), 20602, 2013.

2. LIU X.M., MA M.M., WU H.B., ZHOU Z.B. Identification of Aeolian loess deposits on the Indo-Gangetic Plain (India) and their significance. Science China Earth Sciences, 60 (1), 428, 2017.

3. SINGH A.K. Probable agricultural biodiversity heritage sites in India: XI. The Upper Gangetic Plains region. Asian Again Agi-History, 16 (1), 21, 2012.

4. FULLER D.Q., VAN ETTEN J., MANNING K., CASTILLO C., KINGWELLBANHAM E., WEISSKOPF A., LING Q., SATO Y., HIJMANS ROBERT J. The contribution of rice agriculture and livestock pastoralism to prehistoric methane levels. Holocene, 21 (1), 743, 2011.

5. ANONYMOUS. Soil and trouble. Science, 3, 1614, 2004.

6. DOTTERWEICH M. The history of human-induced soil erosion: Geomorphic legacies, early descriptions and research, and the development of soil conservation - A global synopsis. Geomorphology, 201 (4), 1, 2013.

7. CHEN J., WU H., QIAN H., LI X.Y. Challenges and prospects of sustainable groundwater management in an arid region along the Silk Road economic belt, northwest China. International Journal of Water Resources Development. 34 (3), 354, 2017.

8. CHEN J., QIAN H., WU H. Nitrogen contamination in groundwater in an agricultural region along the New Silk Road, northwest China: distribution and factors controlling its fate. Environmental Sciences and Pollution Research. 24 (15), 13154, 2017.

9. LI P.Y., QIAN H., WU J.H. Accelerate research on land creation. Nature. 510 (7503), 29, 2014.

10. MARTINEZ-MURILLO J.F., NADAL-ROMERO E., REGUES D., CERDA A., POESEN J. Soil erosion and hydrology of the western Mediterranean badlands throughout rainfall simulation experiments: a review. Catena, 106 (9), 101, 2013.

11. WU H., QIAN H. Innovative trend analysis of annual and seasonal rainfall and extreme values in Shaanxi, China, since the 1950s. International Journal of Climatology, 37 (5), 2582, 2017

12. SHEN H., ZHENG F., WEN L., HAN Y., HU W. Impacts of rainfall intensity and slope gradient on rill erosion processes at loessial hillslope. Soil Tillage Research, 155, 429, 2016

13. RAINATO R., MAO L., GARCIA-RAMA A., PICCO L., CESCA M., VIANELLO A., PRECISO E., SCUSSEL G.R., LENZI M.A. Three decades of monitoring in the Rio Cordon instrumented basin: Sediment budget and temporal trend of sediment yield. Geomorphology, 291, 45, 2017.

14. WANG S., FU B.J., PIAO S.L., LV Y.H., PHILIPPE C., FENG X.M., WANG Y.F. Reduced sediment transport in 
the Yellow River due to anthropogenic changes. Nature Geoscience, 9 (1), 38, 2015.

15. LIU G., HU F., MOHAMED A.M., ABD E., ZHENG F., LIU P., XIAO H., ZHANG Q., ZHANG J. Holocene erosion triggered by climate change in the central Loess Plateau of China. Catena, 103 (2018), 160, 2018.

16. KALAT A.B., LASHKARIPOUR G.R., GHAFOORI M., ABBASI A.A. Analysis of Environmental Factors Affecting Variation in In Terrill Erosion under Rainfall Simulation. Polish Journal of Environmental Studies, 27(4) 1573, 2018.

17. QIAO Y., HAO Q., PENG S., WANG Y., LI J., LIU Z. Geochemical characteristics of the eolian deposits in southern China, and their implications for provenance and weathering intensity. Palaeogeogr. Paleoclimate. Palaeoecol. 308 (3), 513, 2011.

18. ZHANG H., LU H., JIANG S., VANDENBERGHE J., WANG S., COSGROVE R. Provenance of loess deposits in the Eastern Qinling Mountains (central China) and their implications for the paleo environment. Quaternary Science Reviews, 43(3), 94, 2012.

19. FANG Q., HONG H., ZHAO L., FURNES H., LU H., HAN W., LIU Y., JIA Z., WANG C., YIN K., THOMAS J.ALGEO. Tectonic uplift-influenced monsoonal changes promoted hominin occupation of the Luonan Basin: Insights from a loess-paleosol sequence, eastern Qinling Mountains, central China. Quaternary Science Reviews, 169, 312, 2017.

20. ZHANG Y.Z., HUANG C.C., PANG J.L., ZHA X.C., ZHOU Y.L., WANG X.Q. Holocene palaeoflood events recorded by slackwater deposits along the middle Beiluohe River valley, middle Yellow River basin, China. Boreas, 44 (1), 127, 2015.

21. ZHAO G., MU X., WEN Z., WANG F., GAO P. Soil erosion, conservation, and eco-environment changes in the Loess Plateau of China. Mountain Research \& Development, 24 (5), 499, 2013.

22. DIBIASE R.A., WHIPPLE K.X. The influence of erosion thresholds and runoff variability on the relationships among topography, climate, and erosion rate. Journal of Geophysical Research: Earth Surface, 116 (F4), 36, 2011.

23. BENTON M.J., NEWELL A.J. Impacts of global warming on Permo-Triassic terrestrial ecosystems. Gondwana Research, 25 (4), 1308, 2014

24. LI Y., WANG Y., TANG C., OFOSU ANIM D., NI L., YU Z., ACHARYA K. Measurements of erosion rate of undisturbed sediment under different hydrodynamic conditions in lake Taihu, China. Polish Journal of Environmental Studies, 23 (4), 1235, 2014.

25. LANGBEIN W.B., SCHUMM S.A. Yield of sediment in relation to mean annual precipitation. Transactions. American. Geophysical Union, 39 (6), 1076, 1958.

26. SUN W.Y., SHAO Q.Q, LIU J.Y., ZHAI J. Assessing the effects of land use and topography on soil erosion on the Loess Plateau in China. Catena, 121 (121), 151, 2014.

27. LIU T.S. Loess and the Environment. Science Press, Beijing, Volume 1, pp. 303, 1985 [In Chinese].

28. LI B.C., LI Z.Z. Paleoclimate Environment Vicissitude of Susceptibility of Loess during the Holocene on the Loess
Tableland Region in Xi'an. Journal of Sichuan Normal University (Nature Science), 40 (3), 404, 2017 [In Chinese].

29. BIAN H., PANG J., HUANG C., ZHOU Y. Geochemical characterization of loess-paleosol sequences: Comparison between the upper reaches of the Hanjiang and Weihe river valleys, China. Journal of Geographical Sciences, 27 (1), 95, 2017.

30. SUN Y.B., JOHN K., AN Z.S., STEVEN C., LIU Z.Y., LIU W.G., LIU X.D., SHI Z.G., ZHENG W.P., LIANG L.J., YAN Y., LI Y. Astronomical and glacial forcing of East Asian summer monsoon variability. Quaternary Science Reviews, 115, 132, 2015.

31. WANG Z.J., JIAO J.Y., RAYBURG S., WANG Q.L., SU Y. Soil erosion resistance of "Grain for Green" vegetation types under extreme rainfall conditions on the Loess Plateau, China. Catena, 141 (141), 109, 2016.

32. LU H.Y., ZHANG H., WANG S., COSGROVE R., SUN X., ZHAO J., SUN D., ZHAO C., SHEN C., WEI M. Multiphase timing of hominin occupations and the paleoenvironment in Luonan Basin, Central China. Quaternary Research, 76 (1), 142, 2011.

33. BENDER S.F., WAGG C., VAN M.G. An Underground Revolution: Biodiversity and Soil Ecological Engineering for Agricultural Sustainably.Trends in Ecology \& Evolution, 31 (6), 440, 2016.

34. LIU G., LIU P.L., YANG M.Y., CAI C.F., XU, W.N., ZHANG, Q., YANG, W. The significance and relationships among substitutive climatic proxies in the Holocene at the middle Loess Plateau in China. Environmental Earth Sciences, 70 (7), 2997, 2013.

35. WANG X.Y., BI H.X., SONG Q.F., LU S.W. Influence of Forest Coverage on Basin Runoff in China's Loess Plateau. Polish Journal of Environmental Studies, 24 (2), 743, 2015.

36. YAO Z.J., LIU Z.F., HUANG H.Q., LIU G.H., WU S.S. Statistical estimation of the impacts of glaciers and climate change on river runoff in the headwaters of the Yangtze River. Quaternary International, 336 (336), 89, 2014.

37. JIANG C., XIONG L.H., WANG D.B., LIU P., GUO S.L., XU C.Y. Separating the impacts of climate change and human activities on runoff using the Budyko-type equations with time-varying parameters. Journal of Hydrology, 522, 326, 2015.

38. SUN J.Z. Quaternary history of Loess Plateau. Science Press, Beijing, 1, 1, 1991 [In Chinese].

39. SHI Y., KONG Z., WANG S. The climatic fluctuation and important events of Holocene mega thermal in China. Science in China (Series B). 22 (12), 1300, 1992 [In Chinese].

40. DENG C.L., YUAN B.Y. Processes of gully erosion and accumulation in the central Loess Plateau of China since the last interglacial. Acta Geographica Sinica, 56, 92, 2001 [In Chinese with English abstract].

41. DU J., ZHAO J.B. Study on soil erosion on the loess highlands in the Guanzhong plain, Shaanxi Province since the Holocene Epoch. Arid Land Geography, 27 (4), 535, 2004 [In Chinese with English abstract].

42. KANECAN J., KONECNA A., PODHRAZSKA J., KUCERA J. Erosion Processes and Sediment Transport during Extreme Rainfall-Runoff Events in an Experimental Catchment. Polish Journal of Environmental Studies, 23 (4), 1195, 2014. 
